\title{
GAMBARAN PASIEN CEDERA KEPALA DI RSUP. PROF. DR. R. D. KANDOU MANADO PERIODE JANUARI 2013 - DESEMBER 2013
}

\author{
${ }^{1}$ Fonda Simanjuntak \\ ${ }^{2}$ Danny J. Ngantung \\ ${ }^{2}$ Corry N. Mahama \\ ${ }^{1}$ Kandidat Skripsi Fakultas Kedokteran Universitas Sam Ratulangi Manado \\ ${ }^{2}$ Bagian Neurologi RSUP Prof. Dr. R. D. Kandou Manado \\ Email: fondasilvania@yahoo.com
}

\begin{abstract}
Head injury is a mechanical trauma to the head that occurs either directly or indirectly, which then can lead to disorders of neurological function, physical function, cognitive, and psychosocial, temporary or permanent. This study aimed to describe patients with head injuries admitted at the Emergency Surgery Prof. Dr. R. D. Kandou Hospital Manado in the period of January 2013 to Desember 2013. This was a retrospective descriptive study. Subjects were patients at the Emergency Surgery Installattion Prof. Dr. R. D. Kandou Hospital period January 2013December 2013 and were diagnosed with head injuries. Gender, age, occupation, causes of head injuroes, and diagnosis obtained from medical records. The results showed that there were 420 patients with head injuries, most of them were males 302 people (71.9\%) compared to 118 females (28.1\%). The climax of incidence was in the age group 15-19 (17.1\%) with the highest profession as student were 138 persons (32.9\%) and the fewest was Army/Police and priest, each of them was 1 patient $(0.2 \%)$. Most of the head injury cases (298 people, $71.0 \%$ ) were caused by traffic accidents and 178 males were diagnosed with comotio cerebral which was the most common diagnosis (40.8\%). Conclusion: In this study, most of the head injury cases were males in the age group 15-19 years. Students were the most frequent background with traffic accidents as the major cause and commotio cerebral was the most common diagnosis.
\end{abstract}

Keywords: head injury, causes of head injury.

\begin{abstract}
Abstrak: Cedera kepala adalah trauma mekanik pada kepala yang terjadi baik secara langsung atau tidak langsung yang kemudian dapat berakibat gangguan fungsi neurologis, fungsi fisik, kognitif, psikososial, dapat bersifat temporer atau permanen. Penelitian ini bertujuan untuk mengetahui gambaran penderita cedera kepala yang masuk ke Instalasi Rawat Darurat Bedah (IRDB) RSUP Prof. Dr. R.D. Kandou Manado dalam periode Januari 2013 - Desember 2013. Penelitian ini menggunakan metode deskriptif retrospektif. Subjek penelitian ialah pasien yang masuk ke IRDB RSUP Prof. Dr. R.D. Kandou Manado periode Januari 2013 - Desember 2013 yang didiagnosis cedera kepala. Jenis kelamin, usia, pekerjaan, penyebab cedera kepala dan diagnosis dicatat dari rekam medik pasien. Hasil penelitian memperlihatkan 420 kasus cedera kepala, sebagian besar berjenis kelamin laki-laki yaitu sebanyak 302 orang $(71,9 \%)$ sedangkan jenis kelamin perempuan 118 orang $(28,1 \%)$. Puncak kejadian pada kelompok umur 15-19tahun $(17,1 \%)$ dengan profesi terbanyak sebagai pelajar/mahasiswa sejumlah 138 orang (32,9\%) dan profesi yang paling sedikit TNI/POLRI dan pendeta masing - masing 1 pasien (0,2\%). Dari rekam medik didapatkan penyebab cedera kepala tersering ialah kecelakaan lalu lintas yang dialami oleh 298 orang $(71,0 \%)$ dan 178 orang didiagnosis komosio serebri yang merupakan diagnosis tersering sebanyak 40,8\%. Simpulan: Pada penelitian ini cedera kepala terbanyak terjadi pada laki-laki dengan kelompok usia15-19 tahun. Pelajar/mahasiswa merupakan profesi terbanyak, kecelakaan lalu lintas merupakan penyebab utama, dan komosio serebri sebagai diagnosis tersering.
\end{abstract}

Kata kunci: cedera kepala, morfologi cedera kepala 
Cedera kepala adalah trauma mekanik pada kepala yang terjadi baik secara langsung atau tidak langsung yang kemudian dapat berakibat kepada gangguan fungsi neurologis, fungsi fisik, kognitif, psikososial, bersifat temporer atau permanen. ${ }^{1} \quad$ Cedera kepala (Traumatic Brain Injury) menimbulkan gangguan yang lebih kompleks bila dibandingkan dengan trauma pada organ tubuh yang lain. Hal ini dikarenakan struktur anatomik dan fisiologis dari isi tengkorak yang bervariasi. Strukturnya berkonsistensi cair, lunak dan padat yaitu cairan otak, selaput otak, jaringan saraf, pembuluh darah dan tulang. $^{2}$

Cedera kepala merupakan salah satu jenis cedera terbanyak di unit gawat darurat (UGD). Dari 100\% pasien trauma lebih dari 80\% disertai dengan adanya cedera kepala dan sekitar $90 \%$ meninggal sebelum tiba di rumah sakit karena adanya cedera otak. ${ }^{1,3}$ Berdasarkan beratnya, cedera kepala diklasifikasikan menjadi cedera kepala ringan (CKR), cedera kepala sedang (CKS) dan cedera kepala berat (CKB) dan berdasarkan morfologi yaitu Komosio Serebri, Kontusio Serebri, Epidural hematom, Subdural hematom, Intraserebri hematom dan Subarachnoid hematom. ${ }^{4}$

Berdasarkan data Riskesdas 2013 Sulawesi Utara menduduki urutan ke 2 untuk angka kejadian kecelakaan di jalan raya dengan persentase 50,5\%. ${ }^{8}$ Kecelakaan lalu lintas terutama kecelakaan sepeda motor terhitung sebagai salah satu penyebab cedera kepala tersering. ${ }^{1,5,6}$

Kulit kepala merupakan lapisan luar kepala yang ditutupi oleh rambut dan terdiri dari 5 lapisan yaitu : skin, connective tissue, arteri, loose areolar dan perikranium. Kulit kepala memiliki banyak pembuluh darah sehingga bila terjadi perdarahan akibat laserasi, kulit kepala akan menyebabkan banyak kehilangan darah. ${ }^{1}$ Tengkorak kepala juga berfungsi untuk melindungi otak. ${ }^{1}$ Dari fungsi diatas dapat dilihat cedera kepala bukan suatu kejadian yang bisa dianggap sepele karena dapat menyebabkan kerusakan saraf, infeksi otak, bahkan kehilangan kemampuan kognitif. $^{7-9}$

Kerugian-kerugian yang didapatkan dari cedera kepala membuat kita harus waspada dan melakukan tindakan pencegahan terjadinya cedera kepala. Tujuan dari penelitian ini untuk mengetahui gambaran penderita cedera kepala di RSUP. Prof. Dr. R. D. Kandou periode Januari 2013 - Desember 2013.

\section{METODE PENELITIAN}

Penelitian ini dilakukan dalam waktu kurang lebih satu bulan, yaitu bulan Desember 2014 dan bertempat di bagian rekam medik BLU RSUP. Prof. R. D Kandou Malalayang untuk mengambil data sekunder dalam bentuk rekam medik dengan jenis penelitian bersifat deskriptif dengan metode retrospektif. Populasi dalam penelitian ini adalah pasien yang datang ke Instalasi Rawat Darurat Bedah (IRDB) RSUP. Prof. R. D Kandou Malalayang pada Januari 2013 sampai Desember 2013. Sampel dalam penelitian ini adalah pasien cedera kepala RSUP. Prof. R. D Kandou Malalayang pada Januari 2013 sampai Desember 2013 yang sudah memenuhi kriteria inklusi yaitu memiliki data lengkap dan diperoleh di bagian rekam medik RSUP. Prof. R. D. Kandou.

Variabel dalam penelitian ini terdiri dari jenis kelamin, umur, pekerjaan, penyebab cedera kepala, dan diagnosis cedera kepala.

Cara pengambilan data dilakukan dengan mencari dan mengumpulkan data penderita cedera kepala dari bagian rekam medik kemudian dilakukan pengelompokan data sesuai dengan variabel yang sudah ditentukan dan diolah secara manual dengan bantuan microsoft excel.

\section{HASIL PENELITIAN DAN BAHASAN}

Dari hasil pengumpulan data yang dilakukan di bagian Rekam Medik BLU RSUP. Prof. DR. R. D. Kandou Manado periode Januari 2013 - Desember 2013, diperoleh 516 data penderita cedera kepala. Dari 516 data penderita ini 420 yang dimasukan dalam penelitian sesuai dengan kriteria inklusi dan eksklusi. Data yng 
diperoleh disajikan dalam bentuk gambar dan tabel.

Gambar 1 menunjukkan sebagian besar penderita cedera kepala ialah laki-laki yaitu sebanyak 302 orang (71,9\%) sedangkan perempuan sebanyak 118 orang (28,1\%). Angka ini mungkin berhubungan dengan aktifitas dan bidang pekerjaan yang berbeda antara laki-laki dan perempuan dimana laki-laki memiliki aktifitas dan bidang pekerjaan yang berisiko untuk terjadinya cedera kepala misalnya mengendarai motor, pekerja bangunan, dll. Hal ini juga sesuai dengan kepustakaan tentang kecenderungan cedera kepala terhadap laki-laki yaitu 2 kali lebih sering dibandingkan dengan cedera kepala terhadap perempuan. ${ }^{10}$

Gambar 1. Distribusi Penderita Cedera Kepala Berdasarkan Jenis Kelamin

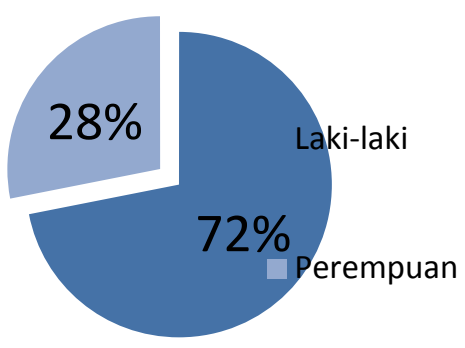

Tabel 1. Distribusi Penderita Cedera Kepala Berdasarkan Umur

\begin{tabular}{ccc}
\hline $\begin{array}{c}\text { Umur } \\
\text { (tahun) }\end{array}$ & Jumlah(orang) & $\begin{array}{c}\text { Persentase } \\
(\mathbf{\%})\end{array}$ \\
\hline $0-4$ & 13 & 3,1 \\
$5-9$ & 28 & 6,7 \\
$10-14$ & 34 & 8,1 \\
$15-19$ & 72 & 17,1 \\
$20-24$ & 54 & 12,9 \\
$25-29$ & 26 & 6,2 \\
$30-34$ & 38 & 9,0 \\
$35-39$ & 30 & 7,1 \\
$40-44$ & 28 & 6,7 \\
$45-49$ & 26 & 6,2 \\
$50-54$ & 22 & 5,2 \\
$55-59$ & 16 & 3,8 \\
$60->60$ & 33 & 7,9 \\
Total & $\mathbf{4 2 0}$ & $\mathbf{1 0 0 , 0}$ \\
\hline
\end{tabular}

Dalam penelitian ini didapatkan angka kejadian cedera kepala terbanyak terdapat pada kelompok usia 15-19 tahun sejumlah 72 orang dengan persentase sebesar 17,1\%, kelompok umur kedua tertinggi adalah kelompok 20 - 24 tahun sebanyak 54 orang atau 12,9\%, dan usia $30-34$ tahun 38 orang atau $9,0 \%$ ada di posisi ketiga terbanyak sebagai penderita cedera kepala (Tabel 1). Hal ini relatif sama dengan the statistic of traumatic brain injury in United States, yang menyatakan kelompok usia beresiko 0-14 tahun, $15-19$ tahun dan >75 tahun sebagai kelompok umur beresiko tapi kelompok umur dengan resiko tertinggi adalah kelompok 15-19 tahun. ${ }^{10}$

Berdasarkan jenis pekerjaan, dari 420 pasien cedera kepala yang memenuhi kriteria inklusi jenis pekerjaan yang paling sering adalah pelajar/mahasiswa dengan jumlah 138 orang atau 32,9\%. Angka yang didapat berhubungan erat dengan hasil dari distribusi cedera kepala berdasarkan kelompok umur tersering yaitu kelompok 15-19 tahun dimana kelompok usia ini adalah kelompok usia pelajar/mahasiswa.

Tabel 2. Tabel Distribusi Penderita Cedera Kepala Berdasarkan Pekerjaan

\begin{tabular}{ccc}
\hline Pekerjaan & $\begin{array}{c}\text { Jumlah } \\
\text { (Orang) }\end{array}$ & $\begin{array}{c}\text { Persentase } \\
\text { (\%) }\end{array}$ \\
\hline Pelajar / & 138 & 32,9 \\
mahasiswa & 61 & 14,5 \\
Petani & 42 & 10,0 \\
Ibu rumah tangga & 37 & 8,8 \\
Swasta & 35 & 8,3 \\
Wiraswasta & 24 & 5,7 \\
Pekerja lepas & 23 & 5,5 \\
Tukang & 23 & 5,5 \\
PNS & 19 & 4,5 \\
Bawah umur & 7 & 1,7 \\
Nelayan & 5 & 1,2 \\
Sopir & 4 & 1,0 \\
Tidak bekerja & 1 & 0,2 \\
TNI / POLRI & 1 & 0,2 \\
Pendeta & $\mathbf{4 2 0}$ & $\mathbf{1 0 0 , 0}$ \\
Total &
\end{tabular}

Dari hasil distribusi berdasarkan umur dan pekerjaan dapat digambarkan juga distribusi cedera kepala berdasarkan penyebab terjadinya. Aktifitas yang tinggi 
dan pergaulan masa remaja membuat kelompok pelajar memiliki mobilitas yang tinggi, kurangnya kesadaran terhadap ketertiban lalu lintas juga dapat dikaitkan dengan tingginya angka cedera kepala yaitu kecelakaan lalu lintas yang dialami oleh 298 orang dari 420 data penderita yang diteliti dengan persentase 71,0\% (Gambar 2). Hal ini sama dengan kesimpulan dalam beberapa penelitian yang menyatakan kecelakaan lalu lintas sebagai penyebab utama cedera kepala. ${ }^{5}$

Gambar 2. Distribusi Penderita Cedera Kepala Berdasarkan Penyebab

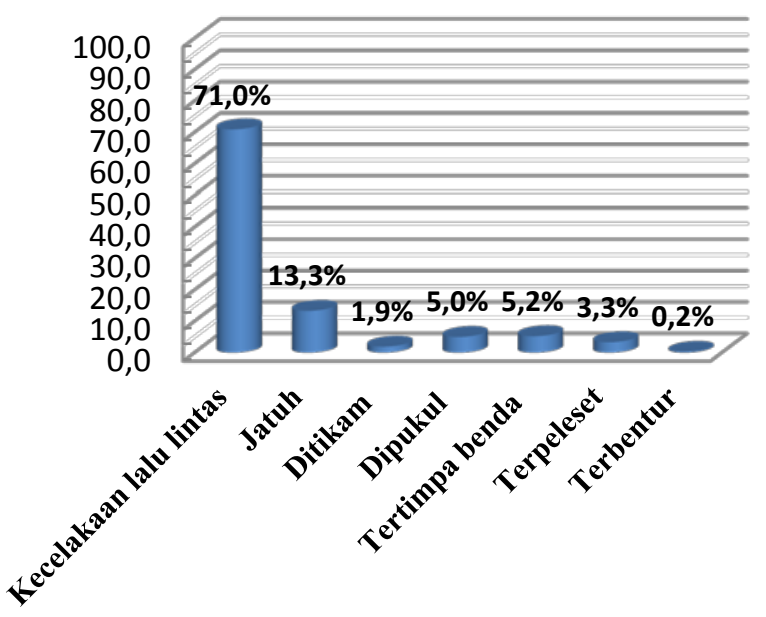

Gambar 3. Distribusi Penderita Cedera Kepala Berdasarkan Diagnosis

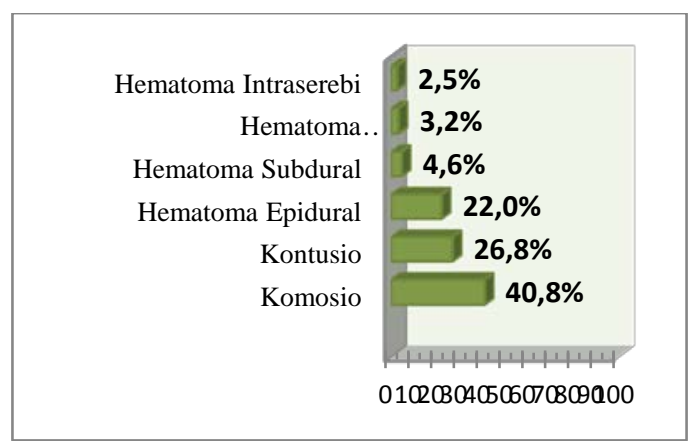

Gambar 3 diatas menunjukkan bahwa terdapat 178 orang $(40,8 \%)$ di diagnosis Komosio serebri dan merupakan diagnosis tersering dalam cedera kepala, 117 orang mengalami kontusio serebri dengan persentase $26,8 \%$ merupakan diagnosis kedua tersering dan hematoma epidural didiagnosis pada 96 pasien (22,0\%) sebagai diagnosis ketiga tersering dalam kasus cedera kepala pada penelitian ini. Hal ini memiliki perbedaan dengan penelitian sebelumnya di RSUP. Prof. DR. R. D. Kandou 2010 tentang profil cedera kepala yang menyatakan kontusio serebri adalah yang tersering dengan angka $36 \% .{ }^{5} \mathrm{Hal}$ ini dapat disebabkan oleh karena adanya perbedaan jumlah sampel yang diteliti.

\section{SIMPULAN}

Berdasarkan hasil penelitian yang dilakukan di bagian rekam medik BLU RSUP. Prof. DR. R. D. Kandou Manado dari bulan Januari 2013 - Desember 2013, diperoleh data mengenai gambaran penderita cedera kepala periode Januari 2013 - Desember 2013 dan dapat disimpulkan Penderita cedera kepala terbanyak berjenis kelamin laki-laki (72\%) dan pada kelompok umur 15-19 tahun (17,1\%), penyebab terbanyak terjadinya cedera kepala adalah kecelakaan lalu lintas (71,0\%) dengan profesi atau pekerjaan terbanyak adalah pelajar/mahasiswa dan diagnosis tersering yang ditegakkan pada pasien cedera kepala yaitu komosio serebri (40,8\%).

\section{SARAN}

Perlu adanya perbaikan dalam pengelolaan registrasi data pasien dalam hal kelengkapan dan kerapihan, diharapkan adanya peningkatan dalam pengelolaan dan penyimpanan data rekam medik di bagian rekam medik BLU RSUP. Prof. DR. R. D. Kandou Manado, agar dapat mempermudah penelitian lebih lanju sehingga pada penelitian berikutnya proses pengambilan data dapat lebih akurat. Perlu adanya sosialisasi tentang tingginya angka kejadian cedera kepala akibat kecelakaan lalu lintas yang ditujukan kepada masyarakat dan lingkungan pendidikan, dan peningkatan kesadaran masyarakat akan ketertiban berlalu lintas mengingat tingginya angka cedera kepala disebabkan oleh kecelakaan lalu lintas, serta perlu adanya kegiatan sosialisasi kepada masyarakat tentang penanganan awal pasien cedera kepala sebelum tiba di rumah sakit terdekat. 


\section{DAFTAR PUSTAKA}

1. American College of Surgeons Comittee on Trauma. Cedera Kepala. In: Komisi Trauma "IKABI" Ikatan Ahli Bedah Indonesia, editors. Advanced Trauma Life Support for Doctors. $8^{\text {th }}$ ed. Jakarta; 2008.

2. Dito A. Cedera Kepala Traumatik. Neurologi update. 2008.

3. Iskandar J. Cedera Kepala. Edisi pertama. Jakarta: PT. Bhuana Ilmu Populer; 2004. p. 1-27.

4. Samir HH, Yaseen MA. Critical Care Management of Severe Traumatic Brain Injury in adults. Scandinavian Journal of Trauma Resuscitation and Emergency Medicine. 2012; 14.

5. Laumart H. Profil Penderita Cedera Kepala di BLU RSUP Prof. Dr. R. D. Kandou Manado periode Januari 2010-Desember 2010. [skripsi].[Manado]: Universitas Sam Ratulangi; 2011.

6. Feibyg TL. Gambaran Korban Meninggal
Dengan Cedera Kepala Pada Kecelakaan Lalu Lintas di Bagian Forensik BLU RSUP Prof. Dr. R. D. Kandou Manado Periode tahun 20112012. [skripsi].[Manado]: Universitas Sam Ratulangi; 2014.

7. Bhangu AA, Keighley MR. Head Injury. In: Mosby Elsevier,editors. Flesh and Bones of Surgery. 2007.

8. Rappaport WA, Brannan S. Head Injury. In: Mosby Elsevier,editors. Flesh and Bones of Surgery. 2005.

9. Mayo Foundation for Medical Education and Research. Traumatic Brain Injury. 20 September 2006 [2014 September16]. Available from: http://www.mayoclinic.com/health/tra umatic-brain-injury/DS00552

10. Brain and Spinal Cord. Brain Injury Statistic. 28 Juli 2009 [15 Januari 2015]. Available from : http://www.brainandspinalcord.org/br ain-injury/statistics.html. 